\title{
KNOWLEDGE IN THE PREVENTION OF LYME BORRELIOSIS AND EXPOSURE TO TICKS IN WOMEN AND MEN STUDYING NON-MEDICAL COURSES IN LATVIA
}

\section{WIEDZA W ZAKRESIE PROFILAKTYKI BORELIOZY Z LYME ORAZ EKSPOZYCJA NA KLESZCZE WŚRÓD KOBIET I MĘŻCZYZN STUDIUJĄCYCH NA KIERUNKACH NIEMEDYCZNYCH Z ŁOTWY}

\author{
Irena Tarelkina ${ }^{1(\mathrm{~A}, \mathrm{~B}, \mathrm{D}, \mathrm{F})}$, Daina Voita ${ }^{1,2(\mathrm{~A}, \mathrm{~B}, \mathrm{D}, \mathrm{F})}$, \\ Małgorzata Tokarska-Rodak ${ }^{3(\mathrm{~A}, \mathrm{C}, \mathrm{D}, \mathrm{E})}$, Anna Pańczuk ${ }^{4(\mathrm{~A}, \mathrm{C}, \mathrm{D}, \mathrm{E})}$
}

${ }^{1}$ Riga Medical College of the University of Latvia

${ }^{2}$ Riga Teacher Training and Education Management Academy, Latvia

${ }^{3}$ Institute of Health Sciences, Pope John Paul II State School of Higher Education in Biala Podlaska, Poland

${ }^{4}$ Institute of Physical Education and Physiotherapy, Pope John Paul II State School of Higher Education in Biala Podlaska, Poland

Authors' contribution Wkład autorów:

A. Study design/planning zaplanowanie badań

B. Data collection/entry zebranie danych

C. Data analysis/statistics dane - analiza i statystyki D. Data interpretation interpretacja danych E. Preparation of manuscript przygotowanie artykułu F. Literature analysis/search wyszukiwanie i analiza literatury G. Funds collection zebranie funduszy
Tables: 3

Figures: 0

References: 15

Submitted: 2017 Jun 12

Accepted: 2017 Jun 22

\section{Summary}

Background. The aim of the following study was to assess the level of knowledge in the prevention of Lyme borreliosis and exposure to ticks in non-medical students, broken down by gender.

Material and methods. The study group comprised 274 students from Latvia, including 229 women and 45 men aged 18-35. As for the research tool, the authors' own questionnaire survey was used.

Results. Latvian male students are more likely to use repellents and more often examine their bodies on return from green areas $(86.6 \%$ and $97.8 \%$ respectively) than women $(66.3 \%$ and $93.9 \%$, respectively). The biggest group of the respondents (35.6\% of the men and $41.1 \%$ of the women) considered that twisting the tick out with tweezers was the correct method of removing ticks. Slightly fewer respondents, i.e. $26.6 \%$ of the men and $36.2 \%$ of the women, opted for tweezing it out with a swift steady movement. In practice, most people do not do this on their own $-28.9 \%$ of the men turn to a doctor / nurse for help and $32.3 \%$ of the women to some other person. Students critically assess their knowledge regarding Lyme borreliosis: $60 \%$ of the men evaluate it as minimal and $53.1 \%$ of the women as average. More than $86 \%$ of the men and $73.4 \%$ of the women in the study group reported being bitten by a tick.

Conclusions: The results of the study reflect the attitudes of Latvian academic youth towards Lyme borreliosis as well as knowledge about the disease and its prevention, which allows for assessing the need for intensifying public education in the subject.

Keywords: Lyme borreliosis, knowledge, prevention, students, Latvia

\section{Streszczenie}

Wprowadzenie. Celem pracy była ocena poziomu wiedzy w zakresie profilaktyki boreliozy z Lyme oraz ekspozycji na kleszcze wśród studentów kierunków niemedycznych z uwzględnieniem płci.

Materiał i metody. Grupe badaną stanowiło 274 studentów z Łotwy, w tym 229 kobiet i 45 mężczyzn w wieku 18 - 35 lat. Narzędzie badawcze stanowił autorski kwestionariusz ankiety. Wyniki. Studiujący mężczyźni z Łotwy częściej stosują repelenty i częściej oglądają swoje ciało po powrocie z terenów zielonych (odpowiednio 86.6\% i 97.8\%) niż kobiety (odpowiednio 66.3\% i 93.9\%). Największy odsetek badanych (35.6\% mężczyzn i 41.1\% kobiet) uważa za prawidłową metodę usuwania kleszcza wykręcanie go pęsetą, nieco mniej usunięcie pęsetą prostym ruchem (26.6\% mężczyzn i $36.2 \%$ kobiet). W praktyce badani najczęściej nie wykonują tej czynności samodzielnie - $28.9 \%$ mężczyzn korzysta z pomocy lekarza/pieleggniarki, a 32.3\% kobiet z pomocy innej osoby. Studenci krytycznie oceniaja stan swojej wiedzy na temat boreliozy z Lyme: $60 \%$ mężczyzn ocenia ją jako minimalną, a $53.1 \%$ kobiet jako średnią. Ponad 86\% mężczyzn i 73.4\% kobiet badanej grupy stwierdziło u siebie zaistnienie pokłucia przez kleszcze.

Wnioski. Wyniki badań odzwierciedlają postawy łotewskiej młodzieży akademickiej i wiedzę na temat boreliozy z Lyme i jej zapobiegania, co pozwala ocenić potrzebę podjęcia zintensyfikowanej edukacji publicznej na ten temat.

Słowa kluczowe: Borelioza z Lyme, wiedza, profilaktyka, studenci, Łotwa

Tarelkina I, Voita D, Tokarska-Rodak M, Pańczuk A. Knowledge in the prevention of Lyme borreliosis and exposure to ticks in women and men studying non-medical courses in Latvia. Health Problems of Civilization. 2017; 11(2): 103-108. doi: 10.5114/hpc.2017.69027.

Address for correspondence / Adres korespondencyjny: Małgorzata Tokarska-Rodak, Institute of Health Sciences, Pope John Paul II State School of Higher Education, Sidorska 102, 21-500 Biała Podlaska, Poland, e-mail: rodak.malgorzata@gmail.com, phone +48 833449900

Copyright: (C) 2017 Pope John Paul II State School of Higher Education in Biała Podlaska, Irena Tarelkina, Daina Voita, Małgorzata Tokarska-Rodak, Anna Pańczuk. This is an Open Access journal, all articles are distributed under the terms of the Creative Commons Attribution-NonCommercial-ShareAlike 4.0 International (CC BY-NC-SA 4.0) License (http://creativecommons.org/licenses/by-nc-sa/4.0/), allowing third parties to copy and redistribute the material in any medium or format and to remix, transform, and build upon the material, provided the original work is properly cited and states its license. 


\section{Introduction}

Lyme borreliosis is the most common infection transmitted by ticks in Europe and North America. The highest morbidity rates are recorded in the countries of Central Europe, Scandinavia and the Baltic States [1]. In Latvia, in 2014, 469 cases of Lyme borreliosis were reported; in 2013 - 454; in 2012 - 724 and in 2011 - 866 [2].

It is Borrelia burgdorferi sensu lato (B. burgdorferi s.l.), the etiologic agent of Lyme borreliosis, together with two tick species - Ixodes ricinus and Ixodes persulcatus, that is responsible for spreading this disease in the country. Ixodes ricinus is common in Europe and Ixodes persulcatus is present, among others, in Russia [3,4]. The results indicate that on average $20-40 \%$ of the ticks are infected with B. burgdorferi s.l. [5]. Humid deciduous forests are a natural habitat for ticks, but these arachnids can also be found in meadows, green suburban areas and in their immediate surroundings: urban parks, gardens and allotment gardens. Such a high prevalence of ticks results in an increased risk of being infected with tick diseases, including Lyme borreliosis [6]. Since the risk of being infected with $B$. burgdorferi s.l is significantly associated with doing outdoor sports, recreation activities or professional activity (foresters, hunters, loggers, forest floor collectors), it is vital to take conscious steps to prevent infection with tick-borne pathogens.

The aim of the study was to assess the level of knowledge of prevention of Lyme borreliosis and exposure to ticks among non-medical students, taking into account the gender factor.

\section{Material and methods}

The study group consisted of 274 students studying at various universities in Latvia, and involved 229 women and 45 men aged 18-35 years (mean 24.3; SD 3.31).

The research tool was a questionnaire consisting of 15 questions. The inquiries concerned possible preventive measures taken while staying in the areas where ticks prevail, including the use of repellents and examining the body after returning from green areas, as well as the knowledge of the correct methods of tick removal from the skin. Students were also asked to assess their knowledge in prevention of tick-borne diseases and to evaluate the knowledge of the Latvian society in this respect. Besides, the respondents answered whether they had been bitten by ticks. They were to indicate the bite sites, state whether ery thema migrans appeared as well as inform about the methods they used to remove the tick.

Statistical analyzes were performed using STATISTICA 7.1 computer software (StatSoft, Poland). In the statistical inference process, the chosen significance level was 0.05 .

\section{Results}

\section{Actions undertaken to prevent Lyme borreliosis and ticks diseases}

When outdoors, tick repellents are significantly more frequently $(\mathrm{p}=0.009, \chi 2=9.2)$ used by the surveyed men. This form of prophylaxis is often used by $26.6 \%$ of the men, while $60 \%$ of them rarely follow it. $13.9 \%$ of the female students declare that they frequently use repellents, whereas $52.4 \%$ do not apply them.

After returning from green areas, $97.8 \%$ of the men check their body in order to detect a tick anchored in the skin; (68.9\% do it often, whereas 28.9\% - rarely). As for women, $93.9 \%$ follow the same procedure; others, i.e. $51.1 \%$, do it often and $42.8 \%$ - rarely). The differences in the responses from men and women were not statistically significant $(\mathrm{p}=0.08, \chi 2=5.0)$.

Students were asked about the areas in which repellents are supposed to be used. Agricultural land has been pointed to by $44.4 \%$ of the men and $60.7 \%$ of the women $(p=0.04, \chi 2=4.1$ ), forest areas $-95.6 \%$ of men and $97.8 \%$ of the women $(p=0.37, \chi 2=0.7)$, meadows $-82.2 \%$ of the men and $98.6 \%$ of the women $\left(p=0.000001, \chi^{2}\right.$ $=26.5)$, orchards $-28.9 \%$ of the men and $67.2 \%$ of the women $(\mathrm{p}=0.000001, \chi 2=23.2)$, urban parks $22.2 \%$ of the men and $62.8 \%$ of the women $(p=0.000001, \chi 2=25.2)$ and other areas $-15.6 \%$ of the men and $6.9 \%$ of the women $(\mathrm{p}=0.05, \chi 2=3.5)$.

The respondents answered the question of how to properly remove the tick anchored in the skin. The answers given are provided in Table 1.

More than $62 \%$ of the male students and $63.8 \%$ of the female students knew that there was no anti-Lyme borreliosis vaccine, and $37.8 \%$ of the men and $36.2 \%$ of the women respectively did not have an opinion on the matter and marked "I do not know". The differences in responses on the part of men and women were not statistically significant $(\mathrm{p}=0.84, \chi 2=0.3)$. 
Table 1. Methods of removing anchored ticks which were considered proper by the surveyed students, broken down by gender

\begin{tabular}{|c|c|c|c|}
\hline \multirow{2}{*}{ Tick removal method } & \multicolumn{2}{|c|}{ Students in the surveyed group } & \multirow{2}{*}{ Statistical significance } \\
\cline { 2 - 3 } & $\begin{array}{c}\text { Men } \\
\text { (\%) }\end{array}$ & \multicolumn{2}{|c|}{$\begin{array}{c}\text { Women } \\
\text { (\%) }\end{array}$} \\
\hline Pull out with fingers & 0.0 & 4.4 & $\mathrm{p}=0.11, \chi^{2}=7.4$ \\
\hline $\begin{array}{c}\text { Remove with tweezers with } \\
\text { a single move }\end{array}$ & 26.6 & 36.2 & $\mathrm{p}=0.21, \chi^{2}=1.5$ \\
\hline Twist out with tweezers & 35.6 & 41.1 & $\mathrm{p}=0.49, \chi^{2}=0.5$ \\
\hline Scratch off with a finger nail & 6.7 & 1.7 & $\mathrm{p}=0.05, \chi^{2}=3.6$ \\
\hline Apply an antiseptic & 31.1 & 25.8 & $\mathrm{p}=0.45, \chi^{2}=0.5$ \\
\hline $\begin{array}{c}\text { Lubricate with fat (e.g. but- } \\
\text { ter, oil) to make it get out }\end{array}$ & 11.1 & 10.0 & $\mathrm{p}=0.82, \chi^{2}=0.1$ \\
\hline Other methods & 17.8 & 25.3 & $0.28, \chi^{2}=1.1$ \\
\hline
\end{tabular}

\section{Opinions on the level of knowledge about Lyme borreliosis and ticks}

There were significant differences in the self-assessment of Lyme borreliosis in the studied group of students broken down by gender ( $p=0.03, \chi 2=6.4$ ). Most men $(60.0 \%)$ and $39.5 \%$ of the women rated it as minimal. $35.6 \%$ of the male students and $53.1 \%$ of the females declared that their level of knowledge on Lyme borreliosis was average. Only $4.4 \%$ of the men and $7.5 \%$ of the women thought that their knowledge in the subject was good. The respondents were also asked whether they wished to broaden their knowledge on Lyme borreliosis and ticks diseases. Significant differences in responses were recorded between men and women $(p=0.01, \chi 2$ $=8.4$ ). Positive answers were given by $62.2 \%$ of the men and $67.7 \%$ of the women, negative by $11.1 \%$ of the men and $20.9 \%$ of the women, and $26.7 \%$ of the males and $11.3 \%$ of females had no opinion on the matter. The surveyed male students believe that their knowledge about Lyme disease in the Latvian society is minimal (80\%) or medium (20\%). On the other hand, women consider that $62 \%$ of the population have minimal knowledge, whereas $37.9 \%$ that it was average $(p=0.02, \chi 2=5.3)$.

\section{Tick bites in men and women studying non-medical courses}

More than $86 \%$ of the men and $73.4 \%$ of the women in the surveyed group of non-medical students in Latvia reported a tick bite $(p=0.057, \chi 2=3.6)$. A single occlusion was reported by $41 \%$ of the males and $36.3 \%$ of the females, multiple bites $-58.9 \%$ by male students and $63.7 \%$ of the females. The tick bite sites indicated by the respondents are listed in Table 2. Erythema migrans occurring after the tick bite was observed only by females (3.6\%). The removal methods of the anchored ticks in the skin applied by members of the tested group are presented in Table 3.

Table 2. Bite site indicated by the surveyed non-medical students, broken down by gender

\begin{tabular}{|c|c|c|c|}
\hline \multirow{2}{*}{ The site of tick bite } & \multicolumn{2}{|c|}{ Students in the surveyed group } & \multirow{2}{*}{ Statistical significance } \\
\hline & $\begin{array}{l}\text { Men } \\
(\%)\end{array}$ & $\begin{array}{c}\text { Women } \\
(\%)\end{array}$ & \\
\hline Upper limb & 28.9 & 24.0 & $p=0.48, \chi^{2}=0.4$ \\
\hline Lower limb & 33.3 & 27.9 & $p=0.46, \chi^{2}=0.5$ \\
\hline Neck & 8.9 & 12.2 & $p=0.52, \chi^{2}=0.4$ \\
\hline Chest & 22.2 & 15.3 & $\mathrm{p}=0.25, \chi^{2}=1.3$ \\
\hline Back & 2.2 & 17.5 & $p=0.08, \chi^{2}=6.8$ \\
\hline Head & 20.0 & 14.4 & $p=0.34, \chi^{2}=0.9$ \\
\hline Stomach & 42.2 & 25.3 & $p=0.06, \chi^{2}=5.4$ \\
\hline Other & 6.7 & 17.5 & $p=0.06, \chi^{2}=3.3$ \\
\hline
\end{tabular}


Table 3. Methods of removing anchored ticks used by the surveyed non-medical students, broken down by sex

\begin{tabular}{|c|c|c|c|}
\hline \multirow{2}{*}{ Tick removal method } & \multicolumn{2}{|c|}{ Students in the surveyed group } & \multirow{2}{*}{ Statistical significance } \\
\hline & $\begin{array}{l}\text { Men } \\
(\%)\end{array}$ & $\begin{array}{l}\text { Women } \\
(\%)\end{array}$ & \\
\hline $\begin{array}{c}\text { It was done by a doctor/ } \\
\text { nurse }\end{array}$ & 28.9 & 18.3 & $p=0.10, \chi^{2}=2.6$ \\
\hline Another person did it & 26.7 & 32.3 & $p=0.45, \chi^{2}=0.5$ \\
\hline $\begin{array}{c}\text { I took it in finders and pulled } \\
\text { out }\end{array}$ & 4.4 & 4.8 & $p=0.91, \chi^{2}=0.01$ \\
\hline $\begin{array}{l}\text { I removed it tweezers with } \\
\text { a single move }\end{array}$ & 15.6 & 7.4 & $p=0.77, \chi^{2}=3.1$ \\
\hline $\begin{array}{c}\text { I twisted it out with } \\
\text { tweezers }\end{array}$ & 17.8 & 15.3 & $p=0.67, \chi^{2}=0.1$ \\
\hline $\begin{array}{l}\text { I scratched it off with my } \\
\text { fingernail }\end{array}$ & 4.4 & 4.4 & $\mathrm{p}=0.98, \chi^{2}=0.0005$ \\
\hline I applied an antiseptic & 17.8 & 10.9 & $\mathrm{p}=0.19, \chi^{2}=1.6$ \\
\hline $\begin{array}{l}\text { I lubricated it with fat (e.g. } \\
\text { butter, oil) to make it get out }\end{array}$ & 0 & 0.9 & $p=0.52, \chi^{2}=0.3$ \\
\hline $\begin{array}{l}\text { I disinfected the spot after } \\
\text { removing the tick }\end{array}$ & 44.4 & 33.6 & $p=0.16, \chi^{2}=1.9$ \\
\hline Other methods & 11.1 & 13.9 & $p=0.60, \chi^{2}=0.2$ \\
\hline
\end{tabular}

\section{Discussion}

As no Lyme borreliosis vaccine is currently available, the only effective way to prevent the disease is to educate people living in areas where B. burgdorferi s.l. spirochete prevails. Education should include issues related to protection against ticks and effective and safe methods of removing the arachnids anchored in the skin. Students pursue active lifestyles, doing outdoor sports, which makes them vulnerable to tick bites. The survey shows that Latvian male students use repellents more frequently and examine their bodies more often after coming back from green areas (86.6\% and $97.8 \%$, respectively) than women (66.3\% and $93.9 \%$, respectively). $13.3 \%$ of the non-medical male students and $33.6 \%$ of female students never use any tick repellents. Further, women have shown more knowledge than men in regard to the areas where repellents should be used. Female students were also more aware where ticks could reside, indicating agricultural land, forests, meadows, orchards and urban parks. However, as the analyses show, despite their knowledge, they are less likely than men to use repellents or examine their bodies after returning from green areas. Nejezchlebova showed that it was women from Czech Republic (89\%) rather than from Poland (17\%) that checked their bodies after coming from the green areas. As for male students, the results indicated that $54 \%$ from the Czech Republic do it, whereas in Poland the figure stood at $4 \%[7]$.

The recommendations by the German Borreliosis Society enumerate the following measures that should be taken to protect one from tick bites: the use of repellents, protective clothing, checking the body for tick bites and their proper removal. Depending on their type, repellents may be used on one's clothing or leather, but what is significant is that their efficacy time is limited and protection is not fully efficient [8].

Because tick bites are usually painless and can be unnoticed, it is advisable to adjust clothing so that the ticks cannot get under garments while in woods and meadows. Clothes should have tight cuffs and collar, pants tucked in socks or shoes, shirt / shirt in pants. One should look at ones' clothing from time to time to detect and shake off the ticks which have not bitten the skin yet. Further, it is preferable to put clothes in bright colours in order to see arachnids better. On returning from green areas, one should examine one's body carefully in search of an anchored tick, paying special attention to the skin of armpits, ears, navel, knee pits, hairy scalp, stomach and groins. Finally, tick repellents should be used as an additional safety measure by spraying clothing and exposed parts of the body [9].

The study conducted in Poland showed that $55 \%$ of the respondents studying Tourism and Recreation reported tick bites [10]. As for the group of Latvian students, the numbers indicated that $86 \%$ of the men and $73.4 \%$ of the women experienced tick bites. 
Both in adults and adolescents the most commonly reported bite sites included: lower limbs 27\% [11] - 59\% [12] and upper ones - 28.8\% [11]. Also in the surveyed group, men and women experienced most bites in those parts of the body.

It is believed that the risk of infection is very low if the tick is removed from the body within 24-48 hours after the bite [13]. It is important to skilfully remove the tick anchored in the skin. It is alarming that $11.1 \%$ of the men and $10 \%$ of the women in the surveyed group consider lubricating the tick with fat (e.g. butter, oil) as a correct method of getting it out, although in practice this method was used by only by $0.9 \%$ of the women. Indeed, more men (6.7\%) than women (1.7\%) believe that scratching the tick off is a proper way of getting rid of it but, in practice, $4.4 \%$ of the men and $4.4 \%$ of the females use this particular method. The highest percentage of the respondents (35.6\% of the men and $41.1 \%$ of the women) considered it proper to remove the tick by twisting it out with tweezers, slightly fewer by removing it with a simple steady movement $(26.6 \%$ of men and $36.2 \%$ of women). In practice, most people do not do this on their own $-28.9 \%$ of the men turn to a doctor / nurse for help and $32.3 \%$ of the women ask another person for help.

Further, 58\% of the respondents studying natural sciences courses in Poland responded that, in case of a tick bite, ticks should be removed with tweezers and the site should be disinfected [14]. In other studies, as Kurnatowski states, students respond differently. Forestry students use protective clothing (87.5\%), repellents $(62.5 \%)$ and remove the tick within the first 24 hours after the bite $(60.0 \%)$.

Incorrect removal of ticks anchored in the body, e.g. with the use of butter, oil, cream, or squeezing, may result in the tick regurgitating into the wound, which increases the risk of infection. As for removing the tick with the tweezers, one should grasp the arachnid close to the skin, and remove it by one swift steady movement. The tick should not be scratched off because it may lead to its crushing and causing micro injuries in the skin through which the ticks (including bacteria) can enter the tissues of the human body. If tweezers are not available, ticks should be pulled with fingers but it is desirable to use a gauze pad to minimize the risk of micro injuries in the skin and infection. Once the tick is removed, the puncture site should be disinfected and hands washed with soap and water [2]. $44.4 \%$ of the men and $33.6 \%$ of the women in the study group disinfected the site after removing ticks.

Finally, it is advisable to observe one's health condition after the bite and consult the physician if erythema appears at the puncture site or other disturbing symptoms that may be related to the tick bite. According to statistics, about two thirds of patients with Lyme borreliosis have removed the tick improperly [2].

Students in the study group critically assess their knowledge of Lyme borreliosis: $60 \%$ of the men point to their minimal level of knowledge on this issue and $53.1 \%$ of the women - to an average one. The vast majority of students ( $62.2 \%$ of the men and $67.7 \%$ of the women) want to broaden their knowledge about tick-borne diseases, but as many as $20.9 \%$ of the females and $11.1 \%$ of the males definitely do not want any further education in this area. Most of the surveyed students ( $80 \%$ of the men and $62 \%$ of the women) believe that the knowledge about Lyme disease in Latvian society is minimal.

\section{Conclusions}

The results reflect the attitudes and knowledge of the Latvian academic youth towards Lyme borreliosis and its prevention, which allows for assessing the need for intensified public education in the subject.

\section{References:}

1. Krūmiņa A, Vasil̦jeva G, Lucenko I, Karelis G, Logina I. Laimborelioze: Literatūras un starptautisko vadlīniju apskats. Doctus. 2013; 8: 10-14 (in Lithuanian).

2. Slimību profilakses un kontroles centrs. Informācija un ieteikumi izglītības iestādēm ērču pārnesto slimību profilaksei. [cited 07 June 2017]. Available from: http://www.spkc.gov.lv/ieteikumi-skolam-unbernudarziem/905/informacija-un-ieteikumi-izglitibas-iestadem-ercu-parnesto-slimibu-profilaksei (in Lithuanian).

3. Vingre I. Biežākās kḷūdas Laimas slimības diagnostikā un ārstēšanā. Latvijas Ārstu Žurnāls. 1999; 4: 24-25 (in Lithuanian)..

4. Mazjānis I, Tirāns E. Laimas slimība. Jums, Kolēgii. 2004; 6: 31-34 (in Lithuanian).

5. Mazjānis I, Tirāns E. Infekcijas slimības (2.izd.). Rīga: autorizdevums. 2006; 1008 lpp (in Lithuanian).

6. Rizzoli A, Silaghi C, Obiegala A, Rudolf I, Hubálek Z, Földvári G, et al. Ixodes ricinus and its transmitted pathogens in urban and peri-urban areas in Europe: new hazards and relevance for public health. Front Public Health. 2014, 1;2:251. doi: 10.3389/fpubh.2014.00251. [cited 07 June 2017]. Available from: http:// www.ncbi.nlm.nih.gov/pmc/articles/PMC4248671/. 
7. Nejezchlebova H, Kiewra D, Žákovská A, Ovesná P. Students' attitudes to tick risks. Ann Agric Environ Med. 2016; 23(3): 437-41.

8. Deutsche Borreliose-Gesellschaft e. V. Diagnosis and Treatment of Lyme borreliosis Guidelines of the German Borreliosis Society. 2010; [cited 07 June 2017]. Available from: http://www.borreliose-gesellschaft.de/ Texte/guidelines.pdf.

9. Rīgas Austrumu slimnīcas infektologi: Ērču aktivitātes sezona ir sākusies [tiešsaite]. [cited 2015 Mar 11]. Available from: https://www.aslimnica.lv/lv/content/rigas-austrumu-slimnicas-infektologi-ercuaktivitates-sezona-ir-sakusies (in Lithuanian).

10. Pańczuk A, Kozioł-Montewka M, Tokarska-Rodak M. Wiedza na temat boreliozy oraz podejmowanie działań profilaktycznych wśród studentów Państwowej Szkoły Wyższej w Białej Podlaskiej. In: Tokarska-Rodak M, Markert R, editors. Społeczne, środowiskowe i biologiczne zagrożenia zdrowia a kształtowanie zachowań prozdrowotnych. Biała Podlaska: Wydawnictwo PSW JPII; 2014. p. 155-165 (in Polish).

11. Bartosik K, Sitarz M, Szymańska J, Buczek A. Tick bites on humans in the agricultural and recreational areas in south-eastern Poland. Ann Agric Environ Med. 2011; 18: 151-157.

12. Pańczuk A, Kozioł-Montewka M, Tokarska-Rodak M. Exposure to ticks and seroprevalence of Borrelia burgdorferi among a healthy young population living in the area of southern Podlasie, Poland. Ann Agric Environ Med. 2014; 21(3): 512-517.

13. Cook MJ. Lyme borreliosis:a review of data on transmission time after tick attachment. International Journal of General Medicine. 2014; 8: 1-8.

14. Kowalczyk A, Kozłowska E, Pacian A, Skórzyńska H. Świadomość studentów na temat występowania i żerowania kleszy w Polsce. Journal of Education, Health and Sport. 2015; 5(9): 469-480.

15. Kurnatowski P, Warpechowska M, Kurnatowska AJ. Knowledge on Lyme disease among foresters. Int J Occup Med Environ Health. 2011; 24(1): 78-93. 